\title{
Sensory Evaluation of Semi-permanent Eyebrow Cosmetics Depending on Different pH Levels.
}

Su-mi Song, Su-jin Yu, Jeong-Hee Kim*

Department of Beauty Design, College of Natural Science, Wonkwang University, Iksan, Jeollabuk-do, Korea

${ }^{*}$ Correspondence: Jeong-Hee Kim, Department of Beauty Design, Wonkwang University, 460 Iksandae-ro, Iksan 54538, Korea

Tel: + 82-63-850 6898

Fax: + 82-63-850-7301

Email:jh@wku.ac.kr

Running Title: Sensory Evaluation of Semi-permanent Eyebrow Cosmetics

This work is part of the Su-jin Yu's Ph.D thesis at the University of Wonkwang, Iksan, Korea 


\begin{abstract}
Purpose: Sensory perception and performance are important aspects for the successful development of cosmetic in the market. In this study, we aimed to prepare semi-permanent eyebrow formulations and perform a sensory evaluation of the same. Methods: We prepared semi-permanent eyebrow cosmetic (SEC) formulations of different pHs (pH 3.0, 4.0, 5.0 and 6.0) and evaluated the sensory attribute on a 5point Likert scale. The test panel comprised women aged 20-39 years who were SEC users and were recruited from an organization via invitation. Results: In sensory evaluation, no difference was noted among samples regarding their spreadability and usability. This is attributable to the fact that the tested samples were prepared in the same form as the liquid type of SECs. The SEC ( $\mathrm{pH} 3.0)$ and SEC (pH 4.0) showed a high satisfaction level for the color strength and tenacity. These results are likely to be related to the $\mathrm{pH}$ regulator components (i.e., citric acid and sodium citrate). Conclusions: The following was the prominent finding of the sensory evaluation: formulations with a low $\mathrm{pH}(<4.0)$ are beneficial for maintaining the coloration (i.e., color strength and tenacity) in SECs.
\end{abstract}

Keywords: Color cosmetics, Semi-permanent eyebrow, pH, Formulation, Sensory evaluation 


\section{Introduction}

The eyebrow cosmetics that had been used are in form of powder, gel, and pencil. Recently, the use of semi-permanent eyebrow cosmetic had been trending worldwide and had been shown to have great advantage (Hong, 2018) in keeping the color on the eyebrows for a certain time period. The long-lasting effect of semi-permanent cosmetics mainly depends on the pH level and properties of the pigments.

The surrounding $\mathrm{pH}$ increases in an area where the $\mathrm{pH}$ is always around 6 due to human homeostasis (Lambers et al., 2006); this leads to the release of the cosmetic ingredients from the particles and their absorption through the skin (Zografi, 1985; Lee \& Kim, 2011). Li et al. (2012) reported that the penetration and absorption of azelaic acid had a strong $\mathrm{pH}^{-}$and vehicle-dependency. In addition, $\mathrm{pH}$ values between 4.0 and 5.0 appeared to provide the most favorable environment for passive diffusion since the concentration of unionized methotrexate would be optimal in this range (Vaidyanathan et al., 1985).

This study was based on the importance of the $\mathrm{pH}$ effect on percutaneous absorption, although the material and formulation used were different. We prepared semi-permanent eyebrow cosmetic formulations at various $\mathrm{pH}$ levels of 3.0, 4.0, 5.0, and 6.0.

Market success is governed by fulfilling research expectations, and by the customer identified sensory attributes that dominate. This implied that sensory analysis significantly contributed to the characterization of individual products (Moravkova \& Filip, 2016). The advantage of sensory evaluation is that the quality of the products is perceived by the end users. The objective of this study is was sensory evaluation of semi-permanent eyebrow cosmetic formulations at various $\mathrm{pH}$ levels, with emphasis of characterization of semi-permanent eyebrow cosmetics.

\section{Methods}

\section{Materials and preparation}

The ingredients of the cosmetics included solvents, thickeners, sequestering agents, preservatives, pigments, and $\mathrm{pH}$ regulators. The $\mathrm{pH}$ regulators were obtained 
as a sodium acid from Duksan Pure Chemicals Co., Ltd. (Ansan, Korea) and as citric acid from RZBC Co., Ltd. (Shandong, China). The pigments and ingredients were purchased from Sigma-Aldrich (USA). The composition of the semi-permanent eyebrow cosmetics is shown in Table 1 .

Phase A was prepared by dissolving $1 \mathrm{~g}$ butylene glycol, $3 \mathrm{~g}$ glycerin, $0.2 \mathrm{~g}$ Coceth-7, 0.2 g PPG-1-PEG-9 lauryl glycol ether, 0.4 g emulgin, 0.05 g disodium EDTA, $0.2 \mathrm{~g}$ methylparaben, and $0.1 \mathrm{~g}$ propylparaben in $53.17 \mathrm{~g}$ of distilled water. Phase B consisted of $0.33 \mathrm{~g}$ orange \#205, $0.3 \mathrm{~g}$ black \#401, and 0.05g red \#106 dissolved in $20 \mathrm{~g}$ distilled water. Phase $\mathrm{C}$ was prepared by mixing $6 \mathrm{~g}$ benzyl alcohol, and $9 \mathrm{~g}$ ethanol. Phase D consisted of citric acid and sodium citrate, which were the $\mathrm{pH}$ regulators. The amount of $\mathrm{pH}$ regulator was different for each sample. A, B, C and $\mathrm{D}$ phases were mixing to manufacture the semi-permanent eyebrow cosmetics. Thereafter, the $\mathrm{pH}$ regulators were added to the semi-permanent eyebrow cosmetics and mixed using the homomixer. The prepared A, B, C and D phases were mixed, defoamed and filtered, and stored in a cold sealed state. The prepared semipermanent eyebrow cosmetics conformed the fundamentals of stability test (Cannell, 1985).

\section{Panel recruiting}

The panels comprised 30 women in the organization who were aged between 2039 years and who were semi-permanent eyebrow cosmetic users. Informed consent was obtained from the subjects after providing them with written and oral information about this study. The study protocol was approved by the ethics committee of Wonkwang University (Registration No. WKIRB 201706-038-02). The panels were blinded to the information on the sample's $\mathrm{pH}$ level and used the prepared semipermanent eyebrow cosmetics (i.e., control, SEC ( $\mathrm{pH} 5.0)$, SEC ( $\mathrm{pH} 4.0$ ) and SEC (pH 3.0)). The subjects were asked to evaluate the sensory attributes of spreadability, color strength, tenacity, usability by the 5-Likert scale.

\section{Color measurement of semi-permanent eyebrow cosmetic}

The $25 \mu \mathrm{L}$ of semi-permanent eyebrow cosmetics was applied on the opacity chart, and the samples were allowed to dry at room temperature for $30 \mathrm{~min}$. The film 
thickness of the semi-permanent eyebrow cosmetics was $10 \mu \mathrm{m}$ in each sample. The samples' colorant was determined using a spectrum colorimeter with $\Phi$ an $8 \mathrm{~mm}$ aperture size (CM-700d Spectrophotometer Minolta, Tokyo, Japan). The color value was measured as the CIE color system ( $\mathrm{L}^{*}, \mathrm{a}^{*}$, and $\left.\mathrm{b}^{*}\right)$. The value for the whiteness index was displayed only when the observer $10^{\circ}$ and the illuminant D 65 were selected.

\section{Sensory analysis}

The panel was requested to score each of the four semi-permanent eyebrow cosmetics after seven days of actual use. Four sensory attributes were chosen and included spreadability on the eyebrow, color strength after cleansing, tenacity on the skin, and usability (Table 2). The scales ranged from 1 (very dissatisfied) to 5 (very satisfied) using a 5-Likert scale.

\section{Statistical analysis}

All the statistical analyses were conducted using SPSS ver. 24.0 software (SPSS Inc., USA). The data were presented as mean and standard deviation. The results were subjected to one-way analysis of variance, and significant differences were determined by the Duncan's multiple range test at $p<0.05$.

\section{Results and Discussion}

From the values of the lightness $\left(\mathrm{L}^{*}\right)$, yellowness $\left(\mathrm{a}^{*}\right)$, and redness $\left(\mathrm{b}^{*}\right)$ components, we can obtain a better understanding of the characteristics of the total color difference among the samples (Melgosa et al., 2018). The color values of the semi-permanent eyebrow cosmetics based on the spectrum colorimeter are shown in Table 3. The mean value of control color values was $L^{*}=31.29, a^{*}=-0.4, b^{*}=-0.23$, which indicated dark gray without yellowness and redness. The color values of the SEC (pH 5.0), SEC (pH 4.0), and SEC ( $\mathrm{pH}$ 3.0) were in the same series of dark brown. Notably, all samples from the semi-permanent eyebrow cosmetics, comprised equivalent amount of the pigment ingredients, although there was a difference between among the color values of samples. There was a tendency of having more reddish and yellowish coloration in the samples that contained $\mathrm{pH}$ regulators. One 
interesting finding was that the $\mathrm{pH}$ regulator affected the colorant of the semipermanent eyebrow cosmetics. In accordance with the present result, Seo et al. (2017) reported that anthocyanin pigments were especially sensitive to $\mathrm{pH}$ and the redness $\left(a^{*}\right)$ increased in acid.

The results of the sensory analysis are numerically summarized in Table 2 and graphically depicted in Figure 2. The spreadability and usability were not significantly difference among the groups. The cosmetics may have contained the controlling factor in the release of the active ingredient from the formulation. This result can be explained by the fact that the tested samples were prepared in the same form as the liquid type of semi-permanent eyebrow cosmetics.

In terms of color strength, satisfaction was higher for the SEC (pH 5.0), SEC (pH 4.0) and SEC (pH 3.0) than for the control. Furthermore, SEC (pH 4.0) and SEC (pH 3.0) had the highest satisfaction for tenacity among the tested samples. These results were likely to be related with the $\mathrm{pH}$ regulator contained in the samples. Most cosmetics or pharmaceuticals are formulated at $\mathrm{pH}$ values at least below 5.0, based on the understanding that such $\mathrm{pH}$ is beneficial for the human skin. Acidic formulations are well known to be more effective at a lower $\mathrm{pH}$ because of the increased skin penetration of the active ingredient (Blaak et al., 2017; Wiechers et al., 2006). The pH range of cosmetics regulated by the Korea Food and Drug Administration (KFDA) is pH 3.0 to 9.0. However, Song et al. (2018) reported that 3.3\% developed skin irritation on human repeat insult patch test after 48 hours of exposure to a semi-permanent eyebrow cosmetic at $\mathrm{pH}$ 3.0. Cosmetic are products used over long periods by the public and their safety is very important (Alani et al., 2013; An et al., 2014; Aschenbeck et al., 2017). The result of that previous study indicated than the acidic pH 3.0 of semi-permanent eyebrow cosmetics may have caused the doubtful reaction with continuous use, although an acidic pH 3.0 cosmetic is available and is regulated by the KFDA.

\section{Conclusion}


Sensory analysis of the use of semi-permanent eyebrow cosmetics showed a significantly high satisfaction with color strength and tenacity at a lower $\mathrm{pH}$ level. The formulation with a lower $\mathrm{pH}$ level (below 4.0) was beneficial for maintaining the coloration (color strength and tenacity) of the semi-permanent eyebrow cosmetic.

\section{Acknowledgments}

This work was supported by the National Research Foundation of Korea Grant funded by the Korean Government (NRF-2017S1A5B5A02025240). 


\section{References}

Alani JI, Davis MD, Yiannias JA. Allergy to cosmetics: a literature review. Dermatitis. 24, 283-290, 2013.

An SM, Ham H, Choi EJ, Shin MK, An SS, Kim HO, Koh JS. Primary irritation index and safety zone of cosmetics: retrospective analysis of skin patch tests in 7440 Korean women during 12 years. International Journal of Cosmetology Science, 36: 62-67, 2014.

Aschenbeck KA, Warshaw EM. Allergenic ingredients in personal hygiene wet wipes. Dermatitis. 28: 317-322, 2017.

Blaak J, Dähnhardt D, Dähnhart-pfeiffer S, Bielfeldt S, Wilhelm KP, Wolfart R, Staib P. A plant oil-containing pH 4 emulsion improves epidermal barrier structure and enhances ceramide levels in aged skin. International Journal of Cosmetic Science, 39: 284-291, 2017.

Cannell JS. Fundamentals of stability testing. International Journal of Cosmetic Science, 7: 291-303, 1985.

Hong SN. Effect of preference for semi-permanent makeup on procedure satisfaction. Asian Journal of Beauty and Cosmetology, 16: 165-177, 2018.

Lambers H, Piessens S, Bloem A, Pronk H, Finkel P. Natural skin surface pH is on average below 5 , which is beneficial for its resident flora. International Journal of Cosmetic Science, 28: 359-370, 2006.

Lee E, Kim B. Smart delivery system for cosmetic ingredients using $\mathrm{pH}$-sensitive polymer hydrogel particles. Korean Journal of Chemical Engineering, 28: 13471350, 2011. 
Li N, Wu X, Jia W, Zhang MC, Tan F, Zhang J. Effect of ionization and vehicle on skin absorption and penetration of azelaic acid. Drug Development and Industrial Pharmacy, 38: 985-994, 2012.

Melgosa M, Richard N, Fernández-Maloigne C, Xiao K, de Clermont-Gallerande H, Jost-Boissard S, Okajima K. Colour differences in Caucasian and oriental women's faces illuminated by white light-emitting diode sources. International Journal of Cosmetic Science. 40: 244-255, 2018.

Moravkova T, Filip P. Relation between sensory analysis and rheology of body lotions. International Journal of Cosmetic Science, 38: 558-566, 2016.

Seo ES, Park CH. Hair dyeing and colorfastness using extracts of blueberry. Asian Journal of Beauty and Cosmetology, 15: 323-332, 2017.

Song SM, Yu SJ, Kim JH. The cell viability \& patch test of semi-permanent eyebrow cosmetic depending on various $\mathrm{pH}$ Levels. Journal of the Korean Society of Cosmetology. 24: 977-985, 2018.

Vaidyanathan R, Chaubal MG, Vasavada RC. Effect of $\mathrm{pH}$ and solubility on in vitro skin penetration of methotrexate from a $50 \% \mathrm{v} / \mathrm{v}$ propylene glycol-water vehicle. International Journal of Pharmaceutics, 25: 85-93, 1985.

Wiechers JW, Kelley CL, Blease TG, Dederen JC. Formulating for fast efficacy. Journal of Cosmetic Science, 57: 191-192, 2006.

Zografi G. Physical stability assessment of emulsions and related disperse systems: a critical review. Journal of Society Cosmetic Chemists, 33: 345-358, 1985. 


\section{국문초록}

\section{$\mathrm{pH}$ 레벨에 따른 세미퍼머넌트 아이브로우 제품의 관능평가}

송수미, 유수진, 김정희

원광대학교 자연과학대학 뷰티디자인학부, 전라북도 익산시, 한국

목적: 세미퍼머넌트 아이브로우 제품은 눈썹에 색상이 일시적으로 착색되어 일정기간 동 안 메이크업 효과가 지속되는 장점을 지니고 있다. 제품의 지속력에 가장 중요한 요인은 제형과 $\mathrm{pH}$ 레벨에 따른다. 방법: 이 연구에서는 액상형의 세미퍼머넌트 아이브로우 화장 품의 $\mathrm{pH}$ 를 조절하여 Control ( $\mathrm{pH}$ 6.0), Sample A ( $\mathrm{pH}$ 5.0), Sample B ( $\mathrm{pH}$ 4.0), Sample $\mathrm{C}(\mathrm{pH}$ 3.0)를 제조하였다. 제조된 시료들의 제품 색상을 측정하였으며, 30명의 패널을 모 집하여 사용 후 관능평가를 실시하였다. 결과: 시료의 제품 색상 측정 결과 Control과 Sample A, B, C의 색상 특성이 다르게 나타났는데, 제조 시 동량의 색재를 사용하였더라 도 $\mathrm{pH}$ 조절제에 의해 제품색의 변형이 나타난 것을 확인하였다. 또한 관능평가 결과 $\mathrm{pH}$ 4.0과 3.0에 해당하는 Sample B와 C의 착색 및 지속력에 대한 만족도가 높게 나타났는 데 이러한 결과는 제품의 $\mathrm{pH}$ 조절에 따라 낮은 $\mathrm{pH}$ 의 제품이 착색 및 지속력이 우수하게 평가되는 것을 알 수 있었다. 결론: 화장품의 관능평가는 제품의 시판화를 위한 가장 실 용적인 평가방법이라 할 수 있다. 이 연구결과에서 낮은 레벨의 $\mathrm{pH}$ 를 적용한 세미퍼머넌 트 아이브로우 제품이 제품 착색 및 지속력에서 우수한 평가 결과를 보였으며 이에 따른 활용가능성을 제시하였다.

핵심어: 색조화장품, 반영구눈썹, $\mathrm{pH}$, 제형, 관능평가 
中文摘要

\section{不同酸碱度的半永久性眉毛化妆品的感官评价}

宋受美，劉秀眞，金柾希*

圆光大学自然大学美容设计学科, 全罗北道益山市, 韩国

目的：感官感知和性能是化妆品市场成功发展的重要方面。本研究旨在制备半永久性眉毛配方, 并对其进行感官评价。方法：制备不同 $\mathrm{pH}$ （pH3.0、4.0、5.0和6.0）的半永久性眉毛化妆品 （semi-permanent eyebrow cosmetic, SEC) 配方, 用里克特五级量表评价其感官特性。 测试小组由 20-39岁的女性组成, 她们是SEC的用户, 并通过邀请从一个组织中招募。结果: 在感官评价中, 各样品在铺展性和可用性方面无明显差异。这是由于测试样品的制备形式与液 体类型的SEC相同。SEC (pH3.0) 和SEC (pH4.0) 对颜色强度和韧性的满意度较高。这些 结果可能与 $\mathrm{pH}$ 调节成分 (即柠檬酸和柠檬酸钠) 有关。结论: 通过以上研究显著发现低pH $(<4.0)$ 的配方有助于在秒内保持着色（即颜色强度和韧性）。

关键词: 彩妆, 半永久性眉毛, $\mathrm{pH}$ 值, 配方, 感官评价 
Table 1. Formulation of semi-permanent eyebrow cosmetics

(Unit: g)

\begin{tabular}{|c|c|c|c|c|c|}
\hline Phase & Ingredient & Control & $\begin{array}{c}\text { SEC } \\
(\mathrm{pH} \mathrm{5.0)}\end{array}$ & $\begin{array}{c}\mathrm{SEC} \\
(\mathrm{pH} 4.0)\end{array}$ & $\begin{array}{c}\text { SEC } \\
(\mathrm{pH} 3.0)\end{array}$ \\
\hline \multirow{9}{*}{ A } & Distilled water & 53.170 & 53.170 & 53.170 & 53.170 \\
\hline & Butylene glycol & 1.000 & 1.000 & 1.000 & 1.000 \\
\hline & Glycerin & 3.000 & 3.000 & 3.000 & 3.000 \\
\hline & Coceth-7 & 0.200 & 0.200 & 0.200 & 0.200 \\
\hline & $\begin{array}{l}\text { PPG-1-PEG-9 lauryl glycol } \\
\text { ether }\end{array}$ & 0.200 & 0.200 & 0.200 & 0.200 \\
\hline & Emulgin $^{\circledR}$ & 0.400 & 0.400 & 0.400 & 0.400 \\
\hline & Disodium EDTA & 0.050 & 0.050 & 0.050 & 0.050 \\
\hline & Methyl paraben & 0.200 & 0.200 & 0.200 & 0.200 \\
\hline & Propyl paraben & 0.100 & 0.100 & 0.100 & 0.100 \\
\hline \multirow{4}{*}{ B } & Distilled water & 20.000 & 20.000 & 20.000 & 20.000 \\
\hline & CI 15510 (Orange \#205) & 0.330 & 0.330 & 0.330 & 0.330 \\
\hline & CI 20470 (Black \#401) & 0.300 & 0.300 & 0.300 & 0.300 \\
\hline & CI 45100 (Red \#106) & 0.050 & 0.050 & 0.050 & 0.050 \\
\hline \multirow{2}{*}{$\mathrm{C}$} & Benzyl alcohol & 6.000 & 6.000 & 6.000 & 6.000 \\
\hline & Ethanol & 9.000 & 9.000 & 9.000 & 9.000 \\
\hline \multirow{3}{*}{$\mathrm{D}$} & Distilled water & 5600 & 5.205 & 3.050 & 5.000 \\
\hline & Citric acid & & 0.145 & 0.500 & 0.500 \\
\hline & Sodium citrate & & 0.250 & 2.050 & 0.100 \\
\hline
\end{tabular}

Control: pH 6.0, did not contain the pH regulator. 
Table 2. Sensory attributes of semi-permanent eyebrow cosmetics

\begin{tabular}{|c|c|c|c|c|c|c|}
\hline \multirow[b]{2}{*}{ Attribute } & \multirow[b]{2}{*}{ Definition } & \multicolumn{5}{|c|}{ Score } \\
\hline & & $\begin{array}{c}\text { Very } \\
\text { satisfied } \\
5\end{array}$ & $\begin{array}{l}\text { Satisfied } \\
4\end{array}$ & $\begin{array}{c}\text { Neutral } \\
3\end{array}$ & $\begin{array}{c}\text { Dissatisfied } \\
2\end{array}$ & $\begin{array}{c}\text { Very } \\
\text { dissatisfied } \\
1\end{array}$ \\
\hline Spreadability & $\begin{array}{c}\text { Pigment } \\
\text { spread easily }\end{array}$ & $\square$ & $\square$ & $\square$ & $\square$ & $\square$ \\
\hline $\begin{array}{l}\text { Color } \\
\text { strength }\end{array}$ & $\begin{array}{l}\text { A pigment or dye's } \\
\text { ability to change }\end{array}$ & $\square$ & $\square$ & $\square$ & $\square$ & $\square$ \\
\hline Durability & $\begin{array}{c}\text { Stayed } \\
\text { on the skin } \\
\text { and eyebrow }\end{array}$ & $\square$ & $\square$ & $\square$ & $\square$ & $\square$ \\
\hline Usability & $\begin{array}{l}\text { Users' tendency to } \\
\text { perceive attractive } \\
\text { cosmetics }\end{array}$ & $\square$ & $\square$ & $\square$ & $\square$ & $\square$ \\
\hline
\end{tabular}

Table 3. The colorant of semi-permanent eyebrow cosmetics

\begin{tabular}{lccccc}
\hline & Control & $\begin{array}{c}\text { SEC } \\
(\mathrm{pH} \mathrm{5.0})\end{array}$ & $\begin{array}{c}\text { SEC } \\
(\mathrm{pH} 4.0)\end{array}$ & $\begin{array}{c}\text { SEC } \\
(\mathrm{pH} 3.0)\end{array}$ & $F$ \\
\hline $\mathrm{L}^{*}$ & $31.29 \pm 0.44$ & $26.78 \pm 0.04$ & $25.39 \pm 0.07$ & $25.33 \pm 0.61$ & $165.51^{* * *}$ \\
\hline $\mathrm{a}^{*}$ & $-0.4 \pm 0.02$ & $2.50 \pm 0.11$ & $2.79 \pm 0.19$ & $3.12 \pm 0.06$ & $17.89^{* *}$ \\
\hline $\mathrm{b}^{*}$ & $-0.23 \pm 0.08$ & $4.63 \pm 0.14$ & $5.58 \pm 0.40$ & $6.28 \pm 0.21$ & $22.17^{* * *}$ \\
\hline $\begin{array}{l}\text { Translate } \\
\text { Image } \\
\text { color }\end{array}$ & & & & & \\
\hline
\end{tabular}

Measurement of data were done in triplicate.

Data are show as mean \pm standard deviation.

The one-way ANOVA was used to compare the color values of control, SEC (pH 5.0), SEC ( $\mathrm{pH}$ 4.0), and SEC (pH 3.0).

Statistical significance was found at ${ }^{* *} p<0.01,{ }^{* \star *} p<0.001$. 
Table 4. The results of sensory evaluation in semi-permanent eyebrow cosmetics

\begin{tabular}{|c|c|c|c|c|c|}
\hline Attribute & Control & $\begin{array}{c}\text { SEC } \\
(\mathrm{pH} 5.0)\end{array}$ & $\begin{array}{c}\text { SEC } \\
(\mathrm{pH} 4.0)\end{array}$ & $\begin{array}{c}\text { SEC } \\
(\mathrm{pH} 3.0)\end{array}$ & $F$ \\
\hline Spreadability & $4.37 \pm 0.67$ & $4.47 \pm 0.73$ & $4.63 \pm 0.56$ & $4.73 \pm 0.52$ & 2.079 \\
\hline Color strength & $\begin{array}{c}3.90 \pm 0.80 \\
b\end{array}$ & $\begin{array}{c}4.4 \pm 0.62 \\
\mathrm{a}\end{array}$ & $\begin{array}{c}4.47 \pm 0.63 \\
\mathrm{a}\end{array}$ & $\begin{array}{c}4.53 \pm 0.63 \\
a\end{array}$ & $5.483^{* *}$ \\
\hline Durability & $\begin{array}{c}3.57 \pm 0.82 \\
c\end{array}$ & $\begin{array}{c}4.10 \pm 0.76 \\
\mathrm{~b}\end{array}$ & $\begin{array}{c}4.40 \pm 0.67 \\
\mathrm{a}\end{array}$ & $\begin{array}{c}4.43 \pm 0.73 \\
\mathrm{a}\end{array}$ & $8.670^{* * *}$ \\
\hline Usability & $4.47 \pm 0.68$ & $4.57 \pm 0.57$ & $4.70 \pm 0.53$ & $4.77 \pm 0.50$ & 1.632 \\
\hline
\end{tabular}

Measurement data were done in triplicate.

Data are show mean \pm standard deviation.

The one-way ANOVA was used to compare the control, SEC ( $\mathrm{pH} 5.0$ ), SEC ( $\mathrm{pH} 4.0$ ), and SEC (pH 3.0).

Statistical significance was found at ${ }^{* *} p<0.01,{ }^{* * *} p<0.001$.

a, b, c: Duncan's post-analysis result between characters. Within the same row, value with the same letters are not significantly different. 


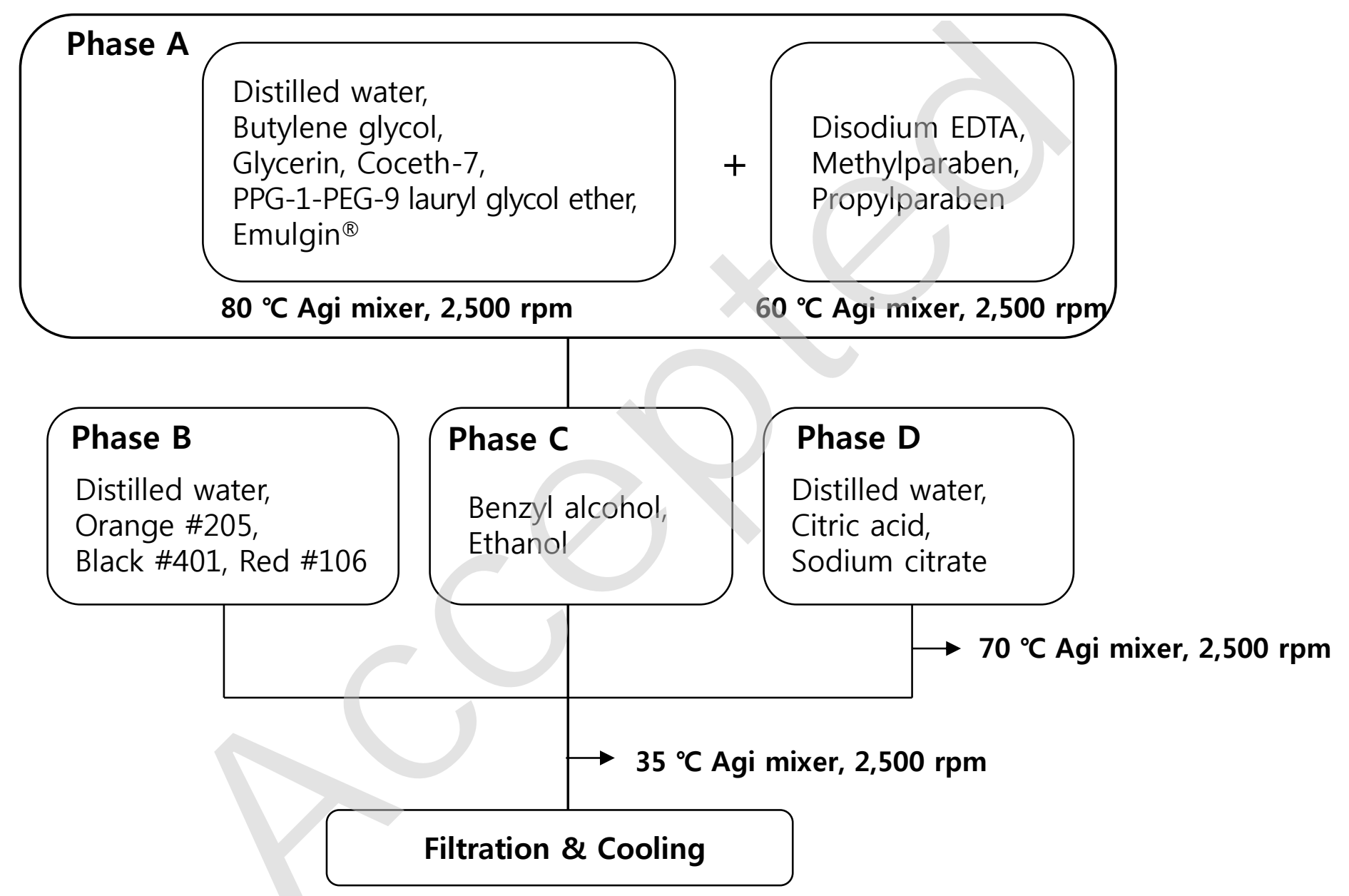

Figure. 1. The preparation process of semi-permanent eyebrow cosmetic. 


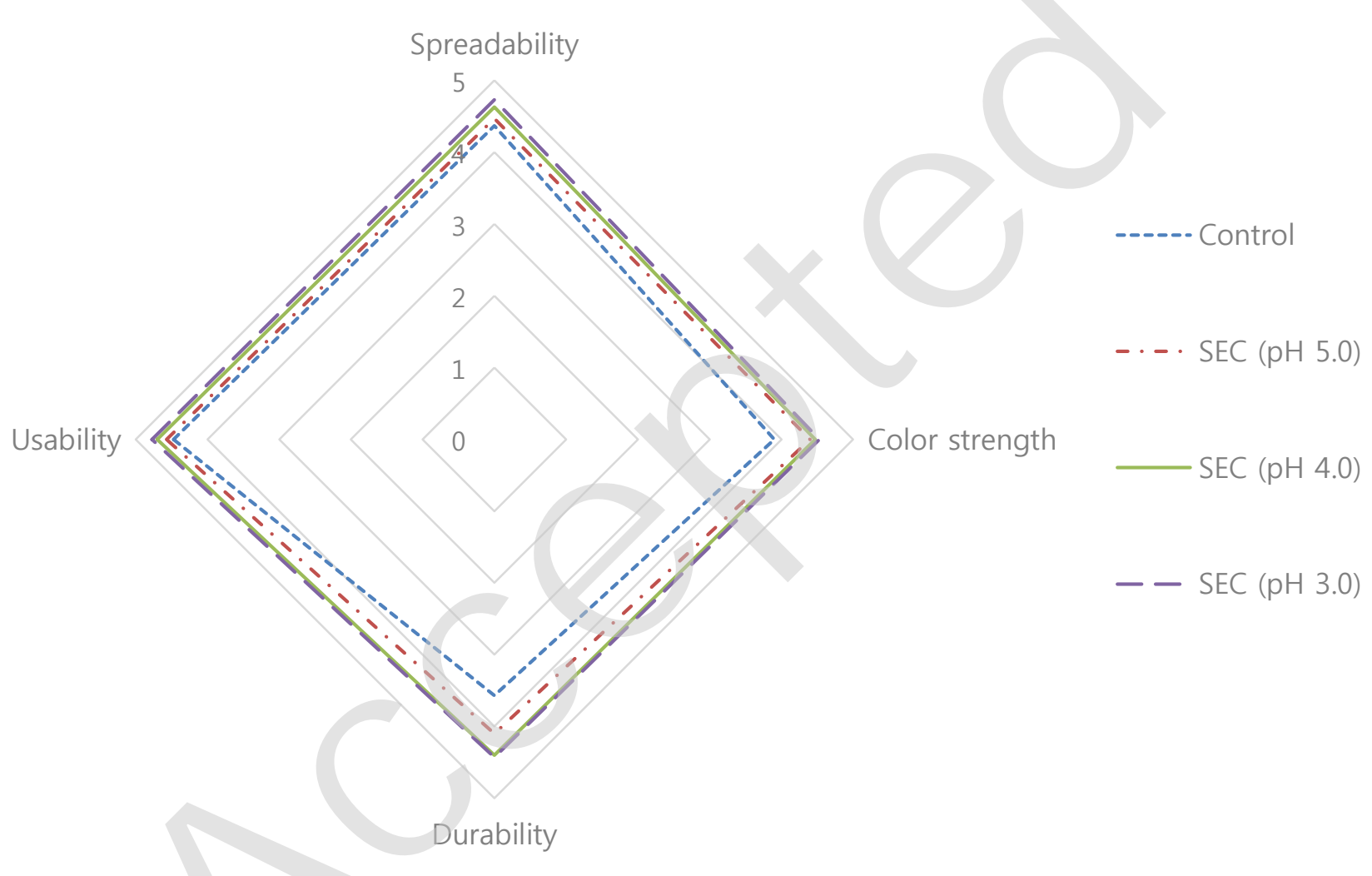

Figure 2. Graphic evaluation of the sensory attributes.

Graphic organize is a visual display that demonstrates relationships between sensory attributes. Control, $\mathrm{pH}$ 6.0, did not contain the $\mathrm{pH}$ regulator;

SEC ( $\mathrm{pH}$ 5.0), semi-permanent eyebrow containing $0.145 \mathrm{~g}$ citric acid and $0.25 \mathrm{~g}$ sodium citrate; SEC ( $\mathrm{pH}$ 4.0), semi-permanent eyebrow containing $0.5 \mathrm{~g}$ citric acid and $2.05 \mathrm{~g}$ sodium citrate; SEC ( $\mathrm{pH}$ 3.0), semi-permanent eyebrow cosmetic, containing $0.5 \mathrm{~g}$ citric acid and $0.1 \mathrm{~g}$ sodium citrate. Data are show as mean $(\mathrm{N}=30)$. 